inOfedia $\quad \begin{aligned} & \text { InMedia } \\ & \text { The French Journal of Media Studies }\end{aligned}$

8.2. $\mid 2020$

What do Pictures Do? (In)visibilizing the Subaltern

\title{
Visible Choices: Black and Gay In/visibility in Howard Cruse's Stuck Rubber Baby (1995)
}

\author{
Nathalie Saudo-Welby
}

\section{(2) OpenEdition}

Electronic version

URL: https://journals.openedition.org/inmedia/2714

DOI: 10.4000/inmedia.2714

ISSN: 2259-4728

\section{Publisher}

Center for Research on the English-Speaking World (CREW)

\section{Electronic reference}

Nathalie Saudo-Welby, "Visible Choices: Black and Gay In/visibility in Howard Cruse's Stuck Rubber Baby (1995)", InMedia [Online], 8.2. I 2020, Online since 22 October 2021, connection on 28 October 2021. URL: http://journals.openedition.org/inmedia/2714 ; DOI: https://doi.org/10.4000/inmedia.2714

This text was automatically generated on 28 October 2021

(C) InMedia 


\title{
Visible Choices: Black and Gay In/ visibility in Howard Cruse's Stuck Rubber Baby (1995)
}

\author{
Nathalie Saudo-Welby
}

1 Howard Cruse (1944-2019) was one of the first openly gay American comic artists. In the 1970s, when many self-aware homosexuals wished to increase their "visibility," Howard Cruse was openly gay, but he made his commitment to increasing gay visibility clear in writing in 1980 when he agreed to edit Gay Comix, and later in 1983 when he created the gay character Wendel for a comic strip in the gay newsmagazine The Advocate. Cruse's coming out as a gay artist gave him an ambivalent form of visibility: by using the subaltern medium of underground comix, ${ }^{2}$ he placed himself in a semivisible cultural zone, on the boundaries of cultural acceptability. This subculture was not entirely inclusive however, for some underground comix featured homophobic content. $^{3}$ In the first half of the 1990s, Cruse temporarily withdrew from some of his professional activities in order to write Stuck Rubber Baby, his most accomplished work. This carefully drawn black-and-white 210-page comic book was published in 1995 by Paradox Press, a division of DC Comics. It won several prizes, such as the Eisner and Harvey Awards, and was praised by critics. The book increased Howard Cruse's visibility as a gay artist, but it never reached commercial success, even after it was republished in 2010 with an introduction by Alison Bechdel, the lesbian author of the graphic memoir Fun Home.

2 Set in the 1960s in the conservative South in the fictional city of Clayfield, based on Birmingham, Alabama, Stuck Rubber Baby contains several narrative levels. On the first level, it tells the story of Toland Polk, a white young man who struggles to come to terms with his sexual orientation. In the frame narrative, Toland narrates his life story to his present-day partner, starting with when he was a child. Through his friendship with a white radical and aspiring folk singer, Ginger, Toland starts meeting people who have been marginalized because of their political commitments and sexual identities: he meets Black civil rights activists, interacts with the gay community in newly racially 
integrated bars, and witnesses interracial same-sex love. Toland then reaches a phase of "racial enlightenment" which results in his increasing involvement in the civil rights movement and his final public confession of his homosexuality. This coming-out narrative is also a carefully documented historical account of the civil rights movement from the Cuban Missile Crisis to Kennedy's assassination (1962-63). ${ }^{5}$ In the acknowledgements, Howard Cruse called the book "a work of fiction, not autobiography," but he conceded that it would not have been written if he "hadn't come of age in Birmingham, Alabama, during the early "60s." The figure of the older Toland towering over page 1 makes us aware that he is in charge of the narrative, looking back on the period of uncertainty which marked the awakening of his queer consciousness. Toland's control over the narrative accounts for its personal bias and for what Andrew Kunka described as its "straightforward and unequivocal" style. ${ }^{7}$ This viewpoint should not be mistaken for Howard Cruse's own, or for the balanced, multifaceted account that can be expected from a historical graphic novel.

3 As Toland gets involved in the civil rights cause, his self-awareness and self-confidence increase, and he learns to accept his homosexuality. Indeed, Stuck Rubber Baby is based on an analogy between being gay and being Black. Gary Richards has described it as a crossover between a coming-out narrative and a "white southern racial conversion narrative," ${ }^{\prime 8}$ praising it as a masterpiece in queer literature. People of color and LGBT people, who adopted the multicolored flag as an emblem of plurality and of their quest for visibility, both have a history of forced invisibility in common as well as their respective quests for cultural and political representation.

4 The "race analogy" in Stuck Rubber Baby has come under critical scrutiny. Gary Richards has drawn attention to the way it romanticizes the African American community, in particular in exaggerating and idealizing their toleration of intragender and interracial sex. Simon Dickel has observed that "after reading the graphic novel, we cannot think of the politics of black and gay liberation as isolated or separate realms," but he adds that this "strategy [...] makes black gay and black lesbian positions invisible."” Jorge Santos goes even further, criticizing the "novel's equation of race and sexuality" as a recuperation that provides an "iconic but sanitized version of civil rights politics," which appropriates civil rights history in constructing queer politics, with the risk of erasing the specificity of the African American position..$^{10}$ However, as Fred Hobson has shown, "both racial integration and homosexuality constituted threats to established roles of race and gender that the South [...] held sacred," so it is perfectly coherent that coming-out narratives should consider how sexuality intersects with ethnicity. A reflection on the "close links between racism and homophobia" has become a common feature of the white racial conversion narrative, ${ }^{11}$ in an effort to reach a better understanding of what it means for minorities to extract themselves from their subaltern position.

5 One of the roles of fiction is to render imaginatively visible what has been ignored, suppressed, or distorted for ideological reasons. By clearly focalizing on and through the unidealized Toland, the graphic memoir lays bare the marks of the position and time from which it was written. Julie Armstrong has shown how some of the connections that Cruse draws between the civil rights movement and the personal memoir allow him to "explode a civil rights movement consensus narrative" by depicting a history more inclusive of gay experience, although she also recognizes that Cruse is not always entirely successful. ${ }^{12}$ Howard Cruse has repeatedly come under 
criticism for speaking from a white position which leaves unexamined the question of the privileges associated to coming out as a white man, so that the intersectional issues may be obscured rather than elucidated. ${ }^{13}$

6 Stuck Rubber Baby addresses the themes of the gaze and of recognition and explores the idea that race and queerness obey similar patterns of visibility. This is counterintuitive, for while Blackness, like queerness, is often envisaged within a binary system (black or white), it is generally thought of as immediately visible, even though there has been a long history of making people of color invisible. The narrator of Ralph Ellison's Invisible Man "recognize[s] [his] invisibility," decides to "accept it," "explore it" and "plunge into it," and later wonders whether he must himself "strive toward colorlessness." ${ }^{14}$ Historically, Black people have been underrepresented, unrepresented or misrepresented. ${ }^{15}$ They have been erased from political life and considered secondclass citizens. LGBT people have also occupied a subaltern position in American society, being a minority dominated by heteronormative discourse and practices. While gayness may be inhabited and performed in more or less visible ways, it is not associated with visible signs of physical difference, which makes it easier to deny its existence. Since identifying gayness is not easy and automatic, it has also been historically difficult to claim a gay identity, and gay people may still choose not to "come out of the closet" at all, or to do so privately, rather than publicly. Looking back to the 1960s from the 1990s, Stuck Rubber Baby engages with the hero's realization of the constraints on visibility regulating the life of the Black minority, Black radicals, and LGBT people. At a time when the need for more visibility came to be felt more intensely by gay men, the book describes the visuality regimes to which race, sexuality and gender were subjected, that is to say the dominant cultural practices-involving sight, vision, (in)visibility and erasure. In action and discourse, these practices articulate a vast field of desires, power, and knowledge. The immediate visibility of Blackness was used to deny political representation, freedom of expression and rights to Black citizens. Gayness, being invisible, was considered as best silenced, its very existence and legitimacy denied.

7 The purpose of this essay is to show that, Stuck Rubber Baby does not simply present the Black search for cultural and political representation as a model for the gay community; rather, the storylines of both Toland's personal coming-out and of the civil rights movement are intertwined so as to make two types of subaltern citizens apparent: a queer subject in the making, who aspires to visibility and representation, but finds it difficult to speak; and oppressed black subjects, tolerant of queerness, who appear as models of the good aspiring citizen, being both "conscious of the gaze" and defiant of it. The book also provides interesting insights into what it means to give someone a look of acceptance and recognition based on the recognition and acceptance of racial and sexual differences. Cruse constructs and makes apparent an eye-to-eye levelling ethos which obliterates the subaltern position. Indeed, while looks are often presented as prejudiced, the depiction of the eye itself can perhaps be free of gender, race or class determinations. It brings us face-to-face with the characters. By looking them in the eye, we see emotions that could be our own and find ourselves identifying with them. 


\section{Questioning Visuality Regimes}

8 Paradoxically for a coming-out narrative, which generally takes the hero from unawareness to acceptance, the hero's homosexuality is made visible and audible in no ambivalent terms in the novel's first pages through the gradual introduction of Toland's present day partner in the course of chapter 1, and through the tale of his only contact with the US Army. ${ }^{16}$ When his draft notice arrives, Toland goes to the recruitment center, where he is made to undress and sit in a row with other draftees. Before the "Don't Ask Don't Tell Directive" took effect in the American Army in 1994, gay men were expected to tick a box on their medical form, indicating their sexual orientation, and those who admitted to being "homosexual" were in effect banned from service. ${ }^{17}$ Homosexuality was thus part of a system of categorization, separation and exclusion making visible what could have remained covert, and forcing into invisibility what was then made apparent. The practice corresponded to Mirzoeff's definition of the "complex of visuality":

A given modality of visuality is composed of a series of operations that can be summarized under three headings: first, it classifies by naming, categorizing, defining - a process Foucault defined as "the nomination of the visible". [...] Next, visuality separates the groups so classified as a means of social organisation. [...] Finally it makes this separated classification seem right and hence aesthetic. [...] Classifying, separating and aestheticizing together form what I shall call a complex of visuality. ${ }^{18}$

9 In panels of varying sizes and perspectives, Howard Cruse shows how the system of visuality which enforces gay invisibility works. The first phase is one of forced exposition. Sitting in a line of men all in their underwear, Toland realizes that his neighbor has an erection and finds it difficult to "keep [his] own reflexes in line." Memories of boys' sexual play in his childhood and of discussion with a counselor come back to his mind, and, acting on a confession he dared not make as a teenager, he suddenly ticks the box "homosexual tendencies" on his medical history questionnaire. ${ }^{19}$ "The zest that the guys in charge brought to making sure everyone knew exactly who among us had 'checked the box' caught me a little by surprise," Toland narrates, as an official shouts "Hey, Sarge! We've got a HOMO here!!!” On the bus ride back home, Toland sits isolated, or segregated, while the word "faggot" buzzes around him. "By the time Clayfield Stadium came into view," Toland explains, "I'd decided that this homo stuff had to get nipped right in the bud!" ${ }^{20}$ Toland's humiliating trial of forced visibility has involved the degrading and alienating process of coming out in a medical questionnaire and becoming part of a category.

Toland, who has been forced to recognize that he is gay, and exposed as such, must paradoxically make his gayness invisible. Having been "brought out of the closet by the United States Army," he "scrambles back" into it. ${ }^{21} \mathrm{He}$ strives to pass as heterosexual and to "positively ra-a-a-a-a-a-diate heterosexuality," ${ }^{22}$ his friend Sammy Noone jokes while slipping his arm around his neck. Toland's heterosexual masquerade is a quest for invisibility, which gradually turns into a search for himself. Toland's disclosure paradoxically initiates a narrative of forced invisibility which ultimately leads him not only to acceptance, but also to the choice of being openly gay by making a very emotional public confession of how he strove to conform with heterosexual standards in "a coward's way." ${ }^{23}$ Both Sammy and Toland engage with performances of masculinity, as described by David Halperin. Outwardly, Sammy is a self-confident 
youth who has no problem accepting his homosexuality. As a popular young man, he does not shrink away from showing signs of femininity, he makes his sexual orientation clear when with friends, and performs his gayness with evident pleasure and an intention to shock. The bottom left-hand panel on page 42 freezes the moment when he kisses a Black gay man, Les, on the lips. Toland is Sammy's polar opposite. While Sammy is fully out as a gay man, exemplifying the "distinctive value that gay male culture places on both style and role-playing," Toland decides to "get into straight drag," so as to "conceal [his] appearance of queerness, [and] to hide the visible stigmata of homosexuality." 24

11 Caught in a system that forces him to repress his sexual desires, Toland becomes characterless, he does not have a sexual life and his professional life is represented as limited. Toland fits with Guillaume Le Blanc's definition of what it is to become invisible as a subaltern: "Invisibility can be understood as the fact of being nondescript a lack that is either claimed or assigned." ${ }^{25}$ Toland is non-homosexual, not heterosexual, he is white but does not identify with his parents' ambivalent, covertly racist, openly non-racist, unenlightened ideology. ${ }^{26}$ In the gas station where Toland works, Howard Cruse shows him kneeling at his gas pump, phallic pistol in hand, answering the customers' tacit injunction to "fill her up," as if enslaved to the heterosexual system. ${ }^{27}$ His boss is a racist and could also be a homophobe. However, while he can tell immediately which customer is Black, saying who is gay would prove more difficult. As a white gay man, Toland is able to remain invisible, because outwardly he fits into the white heteronormative system.

Howard Cruse's graphic style interrogates the question of gender and racial categorization and assignation in its own way. When Fredrik Strömberg included Stuck Rubber Baby in his "visual history" of Black people in comics, he praised the book for making up for their lack of representation in Western comics and for presenting them in a "natural" way. ${ }^{28}$ Cruse's graphic style tends to blur the norms and conventions that have governed the system of visuality in most Western comics, a system often based on gender and race prejudices. ${ }^{29}$ Cruse illustrates how the binary language of skin color is often used with racist overtones. The white militants who befriend and join the Black demonstrators are called "white niggers" by their hecklers. ${ }^{30}$ Toland's boss makes cynical remarks about the fact that he has "show[n] his colors at Russell Park": "Do you think grievin' nigra families wanna look up from their children's caskets an' see your milky puss?" he asks him. ${ }^{31}$ Toland's presence at the demonstration is an affirmative step towards proving that he is not a racist and that he approves of racial equality, and this costs him his job.

Cruse's graphic style is realistic, personal, and resolutely non-binary: it avoids the clear categorization of bodies as white or black, and to some extent, as feminine or masculine. Firstly, the bodies are never fully colored. Cruse's techniques of crosshatching and stippling, and his frequent use of chiaroscuro ensure that skin color is not a clearly categorizable attribute. The cross-hatching is more or less dense depending on the pigmentation of the skin, but also on the quantity of light that falls on the body. In the first line of panels on page 52, Riley looks Black, while Shiloh looks white. I have occasionally turned to the book cover in color because I felt uncertain whether Sammy, who has full lips and curly, almost kinky hair, and frequents Black and integrated venues, was Black or not. In this graphic novel, Cruse has developed a specific graphic technique, involving what Ashley Manchester calls "texturization." The emphasis on 
texture, praised by Alison Bechdel, replaces the traditional use of color, and creates previously unseen connections between the layers of meaning in text and image. Texturization "becomes a visual code through which the reader can visualize identity politics and opens up a queer literacy that posits interpretation, tactility, and imagination as modes of knowing." ${ }^{\prime 2}$ Such a sensory literacy also applies to our perception of bodily shapes.

"cute, cartoony 'bigfoot' style" 33 of the early Barefootz strips to Stuck Rubber Baby, roundness is a constant feature of Cruse's graphic style. The curved lines of the bodies' outlines in Stuck Rubber Baby imply that Black and white bodies, female and male bodies, are represented in similar ways. The characters' features are never angular. Their large, round jaws make them look benevolent, and Howard Cruse is spared the necessity of representing the Ku Klux Klan members in the same way by only drawing their suggestively pointed hoods, and two thin slits for the eyes. They are thus devoid of a central humanizing feature in Cruse's works: expressive eyes.

In Howard Cruse's graphics, the characters' emotions are made apparent by the very careful drawing of their eyes. His characters are often shown in conversation, in twoshots showing only their heads and shoulders. Cruse also uses three-quarter representations, and in moments of emotional crisis, some panels only feature the characters' eye or eyes..$^{34}$ The role and representation of the gaze have sometimes been described as gendered and racialized, because patriarchal values and visual imperialism have shaped the way we relate visually to the world around us. Rebecca Wanzo has written that "African Americans must always be aware of the gaze." ${ }^{35}$ Nicholas Mirzoeff has observed that historically "[v]isuality was held to be masculine, in tension with the right to look that has been variously described as feminine, lesbian, queer, or trans." 36 Gazes, Mirzoeff explains, should be equally distributed and reciprocal in order to ensure the respect and dignity of all those present. The expression "the right to look" is taken from Jacques Derrida's reflections on a collection of photographs by MarieFrançoise Plissart addressing gender roles:

The right to look is not merely about seeing. It begins at a personal level with the look into someone else's eyes to express friendship, solidarity, or love. That look must be mutual, each inventing the other, or it fails. As such it is unrepresentable. The right to look claims autonomy, not individualism or voyeurism, but the claim to a political subjectivity and collectivity: "the right to look. The invention of the other." ${ }^{37}$

16 As visuality tends to objectify and control the observed subject, there is a need for a more equal look, which preserves the other's dignity and autonomy. Comic books both appeal to us and give us a privileged position as viewers and observers by the point of view and graphic style of each image, and Howard Cruse brings the organ of sight under special focus in Stuck Rubber Baby, visually and narratively. Several characters in the book face the choice of becoming publicly visible as part of a minority and are led to assess the personal political implications of that choice. In key moments of visual interaction, when eye contact is either granted or denied, we also become aware that everybody has a right to be looked at for what he or she is and has the duty to look at others - as autonomous subjects - with consideration. 


\section{The Politics of Visibility} ultimately resulted in whites and Blacks living segregated lives, visuality meant surveillance, so that invisibility was both somehow desirable and difficult to achieve. Since the right to be looked at and respected as a human being was violently denied, it had to be vindicated. Within that regime, it was an offense for African Americans to look back at a white person ("reckless eyeballing" still means prolonged eye contact from the dominated to the dominant). In an episode of Stuck Rubber Baby which takes place in a segregated bus in the 1930s, the Black lesbian pianist Marge, whose name evokes her marginal position, has found a trick that allows her to sit in the front: she "does the eyes" (goes cross-eyed) at the white male bus driver. This behavior reverses and subverts the expected pattern of the Black man "recklessly looking" at a white woman. When the bus driver sees her squinting and hears her mumbling incomprehensibly, he does not know how to look at her and cannot hold her gaze. He is so embarrassed that he drops his objections and lets her sit at the front of the bus. Marge subverts the system by passing as more marginal than she is. She makes herself extremely visible as an absolute subaltern: she is old, female, Black; she looks dimwitted or mentally ill, and the reader knows that she is a lesbian. "Embodying caricature can, for the racial other, become a way of being seen," Rebecca Wanzo explains..$^{38}$ By playing to the fear of black racial madness," Marge takes "reckless eyeballing" to a point where her marginality is so extreme that, paradoxically, a place can be found for it.

arge's performance is acceptable because the "spectacle of black trauma" ${ }^{39}$ fits with expectations concerning her lack of responsibility. Looking at the dominant with a look of crazy incomprehension frustrates the mechanism of surveillance: its enforcement becomes purely arbitrary. Back in the thirties, Marge used to perform this public nonviolent act successfully with different drivers so as to bring her forced invisibility to an end, in the same way that, thirty years later, demonstrating, marching or sittingin did for the whole community. In the sixties, "doing the eyes" is now a little act Marge plays with friends ("You be the bus driver, Effie"). It generates a mixture of delight and repulsion in the audience ("Yikes" ${ }^{40}$ ). The scene obeys the "triangulated structure" ${ }^{11}$ analyzed by Rebecca Wanzo, but its effect is felt by the audience rather than by the performing subject, who re-enacts her former subjection in a different form. The performance has become a consensual re-enactment of segregation trauma. Julie Guerrero's work reminds us that such a spectacle is intrinsically "dual-faceted" because the trauma is experienced a second time, as it "becomes spectacularized and put on display for public consumption by a society with a greedy fascination with black suffering." "42 Sammy, Toland and their friends are a mise en abyme of the readers, as spectators of what has become a scene of comic relief. As we witness the re-enactment of Effie's bus ride, our position as consumers is made apparent, making it easier for us to take a critical distance towards the scene. The ambivalence of the performance is typical of Cruse's ambitious narrative, which stands half-way between mainstream "movement fiction" and underground exploration.

Sammy Noone plays a central role in displaying the complex and confused politics of visibility. His name evokes that of the real figure of Sammy Younge, the first Black student activist who was murdered for his militancy. Sammy Younge, who served in the 
US Navy, like the fictional Sammy, was involved in the organization of civil rights protests, and was shot in the face in a gas station in Alabama in 1966 for defying segregation rules in a "whites-only" bathroom. As the organist of the local Episcopal church, the fictional Sammy has a strong identity and is very much in the public eye, even if his last name "No-One" also makes him a figure of the every-gay-man of the future. Claiming Sammy's acquaintance helps Toland dismiss the accusation that he is a cop "workin' undercover" in the Melody Motel. ${ }^{43}$ However, being close to Sammy also represents danger, because the men seen in his company are assumed to be gay.

Sammy's visibility as an out gay man is such that he becomes a sign. When Marge and Effie, the elderly Black lesbian couple who run the Rhombus, a gay bar frequented by Black people, run into Toland, Effie asks "What? Are you straight? I thought you came with Sammy?" ${ }^{44}$ Effie embodies subaltern existence in many ways and has liberal views, but even she has made assumptions about what she saw and judged by appearances. The police are careful not to be taken in by appearances. When they visit the Rhombus, a character named Rex presses a switch, a red light flashes on and everybody shifts to a different-sex partner, so as to deceive the police in the pre-Stonewall context, "like being in a game of musical chairs that nobody had warned you you were playing." ${ }^{45}$ The police pretend that they trust what they see, when it suits them: "Ain't no point at all, except to keep the queers nervous," the pianist Mabel explains to the newcomers. ${ }^{46}$ The visuality system is enforced whenever it is suitable, but it can also be ignored by those who set it in place. What matters is that its existence puts some pressure on the potential targets.

21 Sammy's extreme visibility is his loss: he becomes a gay martyr. After he has accused Commissioner Chopper of being responsible for the Melody Motel bombing in front of the TV cameras, he appears in the news, and a local white supremacist newspaper, the Dixie Patriot, publishes a front page with the title "Pervert on Payroll of Racemixing Church." ${ }^{47}$ One night, Ku Klux Klan men paint the word "Faggot" on his door. After Sammy goes to the offices of the newspaper's headquarters at night in an inebriated state, asking for copies of the pictures they released of him, the house he is sharing with Riley, Mavis and Toland is visited by gay bashers and Sammy is lynched. Toland bumps into his body, dangling from a tree. The practice of lynching provides another link between Black oppression and gay bashing. In conformity with the spectacular nature of lynching, which sometimes turned into mass social events and even "modern theatrical entertainment," ${ }^{48}$ the scene is played out in the open: the KKK men are wearing "no hoods," ${ }^{49}$ and the scene, as we see it, is brightly lit by the headlamps of a car. However, the representation of Sammy's lynching differs significantly from the traditional representation of Black lynching victims, shown swinging from a tree surrounded by indifferent, smiling or posing spectators..$^{50}$ Riley and Mavis appear horrified and Sammy's body is not shown in full, but seen from Toland's perspective, from underneath, with his feet dangling. ${ }^{51}$ The metonymy of the feet echoes an earlier panel featuring Ezra Gable, a fictional gay bank president, who was "murdered in back of the sawmill" by local teenagers. ${ }^{52}$ At the beginning of the comic book, the memory of this murder encouraged Toland to act straight and strive to become straight, whereas the traumatic memory of the shock of Sammy's feet against his head, combined with the gaze of Shiloh, a Black musician who was left paralyzed after the bombing of the Melody Motel, triggers his coming out. Sammy's lynching is a deeply traumatic experience which Howard Cruse connects with Toland's other traumatic memories by using a jagged page layout against a black background..$^{53}$ The recurrent motif of the 
splintered skull letting out arrow-like spikes connects the experience of witnessing violence against the subaltern subjects to a deep emotional crisis of the self which has the capacity of shattering preconceived ideas and previous positions.

The vision of Sammy's lynched body plays a decisive role in Toland's decision to come out publicly in front of an integrated audience. In trying to build his heterosexual persona, Toland has become involved with Ginger, a student, guitarist, and singer who takes part in Black protest. Through her, Toland is brought in contact with a marginal community, composed of the Black activists at their secret meeting place, the Melody Motel, and the frequenters of the Rhombus, an underground gay nightclub. As his outlook on life enlarges, Toland becomes aware that there are alternative ways of looking at things. The civil rights movement brings home to him the necessity of becoming politically visible in demonstrations and marches. Toland never came out to his parents, who died in a car accident when he was in his late teens. After revealing his homosexual tendencies to Ginger, and exploring gay sex with Les, Toland feels the need to come out publicly as a political and moral duty towards the Black and gay victims whose visibility has made them the targets of racist and homophobic attacks. His coming out at the Alleysax, a Black jazz club, takes the form of deliberate personal exposure. In this serious, sentimental performance, Toland goes on stage in front of the integrated "subaltern counterpublic" ${ }^{54}$ who are attending a memorial service for Sammy, the white gay martyr who supported the Black cause. As Toland takes the microphone and delivers his speech, the stories of the Black and gay victims who paid for becoming politically visible interweave. The panels break up into jagged forms: "All the faces I was looking down at were beginning to drop away... like they were spiraling headlong down a weirdly lit shaft that I was in some danger of toppling into myself!" Toland's eyes then "lock onto" those of Shiloh. "I knew I'd find understanding in Shiloh's eyes." 55

Toland's final words "It could have been me" mark his identification and solidarity with Sammy; they signify his acceptance of his sexual orientation; they also reflect his newly gained openness and sincerity towards his white and Black friends ${ }^{56}$ The closet door has turned into a stage curtain which rises in front of a large audience. "Toland's coming out moment is a 'coming into the light' that visually indicates an emotional and personal resolve, ${ }^{157}$ Ashley Manchester writes. Since Toland's coming out involves the act of shedding tears in public, it also contributes to dissolving the gender stereotype associating crying and femininity. Although this public confession potentially exposes Toland to violence, he accepts the burden of his sexual identity and comes out into an identity which is public as well as private, in a political context in which gay privacy was still an important strategy. On the mental stage, this is the third time that, on one of the shards reflecting Toland's traumatic recollection, a panel shows the sign "niggerloving queer" which Sammy's murderers left behind. ${ }^{58}$ The racist homophobes' association of the word "queer" and the polysemic word "love" brings together Sammy's integrationist politics and his homosexuality under the infamous label of interracial sex. The word "queer" acts as a call for resistance against two forms of oppression: the heteronormativity which helps support racism ${ }^{59}$ and the way racist assumptions are often entangled with accusations of sexual transgression.

In a minor key, the other young characters who are coming of age in the narrative also think about how they should negotiate their public image. Toland's first and only girlfriend Ginger is thrown out of university for voicing her political ideas too loudly, 
she then tries to become less visible and fails. Les, Toland's guide into gay sex, lives a harmonious life as a Black gay man, but he also knows that it's preferable to remain unseen when travelling with a white man: "Those ol' slave traders bred real flexible posture into us colored folk. [...] It's gettin' dark ... an' this here's a lonely road an' we got us a black man an' a white man together in this car... an' I don't want no shotgun poppin' out of nowhere to persuade me I made the wrong decision about bein' careful." ${ }^{60}$ At this point, it is difficult to tell who Les fears most: the racists or the homophobes. While keeping a "flexible posture" 61 is a sound policy, Toland's personal experience as recounted in the book suggests that it is not a viable compromise for all young gay men.

\section{Visibility and Choice}

Queer identity in Stuck Rubber Baby is unstable, diversified, and political. Besides the white and Black gay men, the scenes of interracial sex and the Black lesbian couple featured in the book, there is Esmo (or Esmeraldus), a flamboyant drag performer who brings comic relief and warmth to those he meets. Although Esmo is clearly represented as Black, he triumphs in his impersonation of Doris Day, and his gender performances involve self-fashioning and enhanced visibility. As for Mabel, she is "straight but they declared her an honorary dyke" at the Alleysax, Effie explains. ${ }^{62}$ Toland believes himself to be gay, but he has a girlfriend, who is pregnant with his son, and he later starts experimenting with his homosexuality. The story of his coming out suggests that gay identity is truly gained only when it is made public, audible, and visible. This is entirely in line with the period of writing and with Howard Cruse's own gender politics since he is famous for making comics visibly gay and creating a visibly gay readership. "Howard Cruse is frequently referred to as the "Godfather of Gay Comics,' and for good reason," Andrew Kunka explains. "Over nearly a fifty-year career in comics, Cruse broke down barriers in the comics industry, mentored and inspired generations of cartoonists, built a community of queer cartoonists that continues to thrive, and created some of the most vital, significant, and funny comics ever made." ${ }^{3}$ As the editor of Gay Comix between 1980 and 1983, he provided a first publishing venue to new gay artists. "Gay Comix provided a venue and safe space for autobiographical stories that could not be found in mainstream comics or even in most undergrounds." ${ }_{64}$ Alison Bechdel has praised Gay Comix for making her realize that there was such a thing as queer comics and considers this discovery as a decisive step in her own career. ${ }^{65}$

In Stuck Rubber Baby, becoming actively gay involves making oneself visibly so. As they stand in the queue outside the gents toilets, Les, who is the Black gay son of Reverend Pepper and Anna Dellyne, tells Toland that if Martin Luther King were to ask him to stop being gay, he would respond by asking him to stop being Black: "You gotta quit bein' gay' 'Just as soon as you stop bein' negro."” ${ }^{66}$ In his recent analysis of civil rights narratives, Jorge Santos, who regards Les as Howard Cruse's "mouthpiece," ${ }^{77}$ criticizes Les's answer for implying that gayness is inborn and inevitable, like Blackness. ${ }^{68}$ However, one could also interpret the gerund in "being negro" as performative, and not the simple copula attaching a subject to a predicate. Just as Martin Luther King was actively and visibly Black, Les implies that his homosexuality cannot be kept dormant and has to express itself in behavioral, possibly even political, choices. ${ }^{69} \mathrm{I}$ understand Les's epigram to mean that gayness, like Blackness, may be more or less asserted, in 
proportion to one's political conscience. The presence of a "SILENCE= DEATH" poster on the walls of the place the older Toland shares with his male partner is a reminder that political commitment has private and public implications: it can speak of the mutual understanding and sincerity in their intimate life, but it also suggests an active, visible political engagement outside home (207). Ironically, Cruse's black-and-white memoir erases the color pink in the poster.

Howard Cruse's graphic style makes skin color part of a moving spectrum, so Blackness and gayness are never absolute and may be asserted at different degrees, which makes them equivalent to political engagement or statements. Just as gender is in part a performance, Black identity can be more or less externalized and internalized. This perspective evokes the question of Ralph Ellison's invisible man in his 1947 novel: "Could they recognize choice in that which was not seen?"70 Blackness is rendered visible through the unnamed narrator's personal commitment. His attitude towards his own invisibility has changed: he no longer perceives himself as invisible because of a lack of representation and acknowledgment, but he perceives his invisibility as a form of empowerment, allowing ambivalence, dissimulation and silent rebellion: "Well, I was and yet I was invisible, that was the fundamental contradiction. I was and yet I was unseen." ${ }^{11}$ Howard Cruse's choice of making himself visible "underground" as a gay cartoonist emulated the choice of the Black and gay characters in his graphic novel. One may or may not choose to make one's sexual identity visible, so that coming out of the closet turns sexual orientation into a chosen experience, contrary to the imposed assignation depicted in the US Army episode..$^{72}$ While in the 1950s and 1960s, it was politically advisable for gay men to remain under cover, in the period when Howard Cruse was writing, the message in the LGBT community was that coming out was a responsible thing to do because greater queer visibility would increase the acceptance of queerness and provide role models to young gays and lesbians. However, homosexual people may choose to claim their right to remain invisible, because, some activists argue, queerness is a private matter which is better kept silent in the interests of the people concerned. In her analysis of the idea that "the personal is political," the political scientist Patricia Boling argued in 1996, drawing from examples such as the "outing" of gay and lesbian people, that privacy is protective and that "sexual choices cannot be determinative of our political position": "The tyranny of transparency may parallel the exclusion of homosexuality by heterosexuals." ${ }^{13}$ There are pragmatic considerations which undermine the principle that individual engagement should be made visible. Besides, uncloseting is a structure that may not reflect the experience of queer people of color, as it does white people. After Toland's public confession, Les determines to keep a more open profile: "my slumping days are over," he declares enigmatically, ${ }^{74}$ as though the door of his closet was not opened wide enough. As Marlon B. Ross explains, the closet paradigm tends to become "an easy common denominator for same-sexual identity." 75 Toland's account is governed by his own politics of in/visibility, which may not fully reflect the experience of queer people of color, even if they are present in the graphic novel. Several critics have observed that Black queerness is represented as somewhat unproblematic in Stuck Rubber Baby, in ways which ignored the specificity of the Black queer position and the existence of white privilege. ${ }^{76}$

Howard Cruse brings a sense of closure to Stuck Rubber Baby by making all its characters have a say about whether they should become more visibly committed, politically, professionally, or ideologically, a dilemma involving major changes in their private 
lives. These analogies increase the accessibility and didacticism of the comic book, which targets a wider readership than Howard Cruse's other works. By moving to New York, as a single childless woman, Ginger decides to try and make a public career as an artist. Anna Dellyne made the opposite choice. While her husband, the Reverend, is bound to a public life, she chose to withdraw from her public life as a Black jazz singer in favor of domestic privacy. She now only sings freedom songs and religious hymns, but her song "There is a secret in the air" is a leitmotiv which hovers over the novel as a prolepsis of Toland's coming out. ${ }^{77}$ Anna Dellyne, who wants to avoid being in the spotlight, provides a link between the question of how public a star may want to be and the dilemma of Black and gay people who may prefer to step back from excessive visibility. ${ }^{78}$ At the end of the book, even Orley, the "redneck" confesses his racist, homophobic sins to Toland, who does not grant him forgiveness. ${ }^{79}$ These contrasts prove that the universe of Stuck Rubber Baby is not idealized, and till the end, the main character remains convinced of the danger of "looking bigotry too squarely in the eyes." ${ }^{\prime 0}$ The realism of the narrative implies that political imperatives remain tied to pragmatic considerations which limit how far an individual may go to stand by his or her cause.

\section{The Right to be Looked at}

Howard Cruse's engagement with the question of visibility also touches on the issue of the recognition granted or denied in someone's gaze. Unsurprisingly, the gaze holds immense power for good or ill in Howard Cruse's works. An early Barefootz strip of 1973 offers a comical perspective on the way the eye can obliterate rather than reveal. The aspiring artist Headrack (who came out as gay in a story published in 1976) follows Barefootz's advice of finding inspiration with Glory, a female-gendered creature who hides under a bed. Headrack's visual encounter with Glory, which he describes in ecstatic, hyperbolic terms, is materialized by a thick light ray and leaves him star eyed. However, when he unveils his work, a life-size, heavily made-up female eye drawn with photographic realism can be seen staring out of the white canvas. "Of course sometimes the execution falls short of the conception!" (bold in the original) Headrack comments. ${ }^{81}$ Although technically successful, the painting is an anticlimax in several respects: it is entirely conventional in terms of style and subject matter, and Headrack has been unable to look beyond the organ of sight, which here epitomizes the heteronormative creative tradition under the supervision of the muse. In his comments on his early Barefootz strips, Cruse narrates an autobiographical experience with a symbolic dimension, which stands as the serious counterpart to the cynical humor of the comic strip. He tells how, as a youth, on an acid trip, he experienced the eye's quasi-mystic power for transformation and reciprocity. This was also the moment when Cruse became conscious of his love for his roommate Don. As he looked into the eyes of his future lover, the contours between mental, physical, and gender categories became blurred and there rose in his mind a vision of the infinite plasticity of the human form fluctuating in relation to the light being shed on it and the perspective from which it is seen:

Don's face came furiously alive. Like bubbles breaking the surface of boiling water, one face replaced another. An old face changed into a new one, then became old again. The transformations accelerated: skin colors darkened and lightened as though racial heritage were a mere trick of lighting. Wrinkles came, then vanished; 
hair lengthened and shortened; bone structure expanded and contracted with breathtaking fluidity. The shell of flesh that normally encased and limited him, defining Don as a being both spacially separate from other humans and distinct from them in bearing and gender, dissolved before my eyes, leaving me struck with his spiritual link to all the people of this planet - the women as well as the men. And I realized that when the face I saw was female, it was no less the Don I loved than when it was male. During all of this the still, blue eyes at my vision's center didn't change. A strong, secure, comforting presence, they smiled through the rippling hallucinations and kept me anchored. ${ }^{82}$ about the primacy of machismo and the inherent emptiness of a faggot's love." ${ }^{83}$ The gaze or subjective viewpoint remains the measure of things, but through Cruse's anchoring in Don's "still, blue eyes," it is decentered from cis/hetero-normative standards. As the vision unfolds, his points of reference change, their mutual gaze is able to defeat prejudices and to become a basis for mutual respect and love. In the comic strip Barefootz, the friends' toleration of all forms of life extends to excessively invasive cockroaches, with farcical results. ${ }^{84}$ In Stuck Rubber Baby, the same theme is submitted to a serious political treatment: the reader is given to feel how a mutual look of respect can help build or destroy somebody's identity. A lot of importance is given to the looks of rejection that are directed at Black otherness and at those who are called "fags" or "faggots." In a few episodes which may have been inspired by real-life experiences collected from witnesses, Cruse exposes the damaging effect of looks of violent denial. Even bloodhounds can give such looks: "Being white, I'd never looked a Clayfield police dog in the eye, but plenty of the folks around me clearly had," Toland comments on the Russell Park sit-in. ${ }^{85}$ Howard Cruse brings out the need for looks of recognition and respect and, through Sammy, he shows that gaining the right kind of visibility is a first step towards self-acceptance. Being looked at and recognized for what one is is a fundamental psychological need and possibly even a right.

In his private life, Sammy has been denied his father's look of recognition and acceptance, and this has left him psychologically wounded. Sammy tries to defeat the homophobic system by making his father accept him for what he is. When he is in need of money, he visits his father, narrates his life-story to him and demands the right to be looked at as he is. Mr. Noone is represented as the embodiment of an intolerant, unfeeling patriarchy. Several panels feature him sitting paralyzed in an armchair, next to his wheelchair, apparently dumb, spectacled but seemingly blind to what is happening around him. As in the pages depicting Sammy's lynching, the layout breaks down. Three splash pages represent Sammy's father's frozen face growing larger and larger.$^{86} \mathrm{Mr}$. Noone represents a regime of visualization which is absolute, threatening, and capable of denying true identity. The panels featuring his son are of varying shapes and sizes, scattered on the pages. "so LooK AT ME, DAMMIT!" Sammy shouts in a panel which only features one of his frowning eyes. In the next panel, we see his head and shoulders, in a humble posture, as he meekly says "Look at me. This is the monster you're so afraid of." ${ }^{87}$ As his first action on seeing his father is to lift his armchair and to knock him out of it, the angelic-looking Sammy is given a less attractive side. The reader's view of his character is likely to resemble that of Riley, who condemns him for having no pity for his crippled father. ${ }^{88}$ This scene and its layout are echoed in the episode, commented on above, when Toland's eyes connect with the smiling, benevolent eyes of the paralyzed Shiloh, and he feels empowered as a result. Sammy's search for understanding fails; Toland's own quest for the right kind of visibility is a 
success. In these two episodes, the eye is given enormous power, both damaging and soothing.

\section{Conclusion}

Stuck Rubber Baby engages with the questions of visuality and visibility in a medium which, traditionally, has contributed to fixing some of the ways we visualize others, but which, with the advent of underground comix in the 1970s, has also come to question in radical ways assumptions about what can be visually represented and how. When a Texan pressure group challenged the American Library Association's classification of Stuck Rubber Baby as for "young adults," because of its depiction of masturbation and gay love, they were trying to deny these subjects some of their acceptability as themes of discussion. ${ }^{89}$ People of color have long been represented in written and visual works, but "[t]here are simply not enough images of Black people in the mainstream not to be critical of the way they are constructed and portrayed." ${ }^{90}$ As Rebecca Wanzo demonstrates in her study of Black caricature in comics and cartoons, the representation of nonwhites in comics has remained shaped by a legacy of racist caricatures and racialized discourse, and nonwhites belong to a liminal zone in the "visual grammar of citizenship," in which they appear alternatively as imperfect citizens or as idealized citizens. ${ }^{91}$ By deliberately avoiding negative stereotypes, Cruse occasionally idealizes his Black activists and Black queer characters. ${ }^{92}$ Some of them resemble what Wanzo would describe as counter-caricatures, depicting the "ideal black aspirant citizen." ${ }^{93}$ It does not follow that Stuck Rubber Baby simplifies and recuperates Black history to serve LGBT interests; the novel is not strictly about LGBT rights, but rather about becoming visible as part of a minority and about the terms in which white gay men can confront this question. Fred Hobson has noted that it is no coincidence that Lillian Smith, the author of Killers of the Dream (1949, 1961), an early racial conversion narrative, was a lesbian: "I would submit that her sexual identity was a major factor - just how major she herself perhaps did not fully recognize - in the making of Smith as a bold racial commentator." ${ }^{94}$ Howard Cruse's graphic novel makes readers witness experiences of forced invisibility in a way which increases their awareness of what being invisible as a subaltern is. His graphic style creates a spectrum of continuity between whites and nonwhites which defeats binary systems of representation. With the civil rights movement as a backdrop, the novel also addresses the question of the right to look and our right to look, which Mirzoeff calls "unrepresentable." ${ }^{95}$ Howard Cruse's use of two-shots and close-ups on the eye, his technique of blowing the panels up in jagged fragments at traumatic moments, so as to explode the all-inclusive gaze, invite readers to become experts of eye-to-eye interaction.

Stuck Rubber Baby was conceived in the period when the term "queer" received its contemporary non-pejorative use, and queer politics and queer theory were being defined. It focuses on marginalized, minoritarian identities that waver between invisibility and forced exposition, and are submitted to reifying and distorting gazes. The graphic novel does not entirely fulfil a queer agenda because it does not "take race seriously as a complication of sexual identification, and sexuality seriously as a complication of racial identity. ${ }^{16}$ However, by focusing on the way vision is articulated on the character's choices about how they manage their own visibility, Cruse's fictional 
autobiography contributes to an exploration of how "blackness and queerness intersect in relation to visual economies undergirded by a politics of visibility that sometimes does and sometimes does not accommodate cultural as well as material privilege both within and outside queer communities." ${ }^{17}$ The fictional Toland is more involved in the civil rights movement than Howard Cruse was, but his personal bias informs the narrative, and requires that we identify with him, but also that we take a step back and wonder what his uninitiated and naïve gaze not only uncovers but distorts. The closeting pattern which structures Toland's account may not be an accurate representation of what being gay means for all men. For instance, Kai Linke considers that Stuck Rubber Baby "remains firmly committed to the value of an (implicitly white) politics of gay visibility," ${ }^{98}$ and that this makes its racial politics problematic. There are indeed questions which Cruse's decisive move towards liberating a queer voice leaves unanswered, such as Marlon Ross's inquiry: "what does it mean for African Americans to uncloset their sexuality within the context of a racial status already marked as an abnormal site over and against white bourgeois identity and its various signifiers of racial normativity?" 99 While Cruse's graphic memoir undeniably carries a political message, it is not certain that it can speak intersectionally about gay visibility politics outside the spectrum of the white middle-class perspective it openly adopts. The answers it elicits must ultimately lie with the readers of its complex and ambitious visual messages.

\section{BIBLIOGRAPHY}

Anon. “Censorship Roundup.” School Library Journal 50, no. 10 (October 2004): 26.

Anderson, Ho Che. King. Seattle: Fantagraphics, 2004.

Armstrong, Julie Buckner. "Stuck Rubber Baby and the Intersections of Civil Rights Historical Memory." In Redrawing the Historical Past: History, Memory, and Multiethnic Graphic Novels, edited by Martha J. Cutter and Cathy J. Schlund-Vials, 106-128. Athens: University of Georgia Press, 2018. < accessed on January 7 2021>

Aubert, Nicole and Claudine Haroche. Les tyrannies de la visibilité. Toulouse: ERES « Sociologie clinique », 2011.

Bechdel, Alison. Fun Home: A Family Tragicomic (2006). Boston/New York: Mariner, 2007.

Berger, Martin A. Sight Unseen. Whiteness and American Visual Culture. Berkeley/Los Angeles: California UP, 2005.

Boling, Patricia. Privacy and the Politics of Intimate Life. Ithaca: Cornell UP, 1996.

Bordelon, David. "Picturing Books: Southern Print Culture in Howard Cruse's Stuck Rubber Baby." In Crossing Boundaries in Graphic Narrative: Essays on Forms, Series and Genres, edited by Jake Jakaitis and James E. Wurtz, 107-122. Jefferson: McFarland, 2012.

Buhle, Paul. “Comics as History.” Reviews in American History 35, no. 2 (June 2007): 315-323. 
Cruse, Howard. Early Barefootz. Seattle: Fantagraphics, 1990.

Cruse, Howard. "The Long and Winding Stuck Rubber Road". <accessed on January 7 2021>

Cruse, Howard. The Other Sides of Howard Cruse. Los Angeles: Boom!, 2012.

Cruse, Howard. Stuck Rubber Baby. New York: Paradox, DC Comics, 1995.

Delany, Samuel R. "Some Queer Notions about Race." In Dangerous Liaisons: Blacks, Gays, and the Struggle for Equality, edited by Eric Brandt, 259-289. New York: New Press, 1999.

Dickel, Simon. “'Can't Leave Me Behind': Racism, Gay Politics, and Coming of Age in Stuck Rubber Baby." Amerikastudien / American Studies 56, no. 4 American Comic Books and Graphic Novels (2011): 617-635.

Donald, James and Ali Rattansi, eds. 'Race', Culture and Difference. London: Sage, Open University, 1992.

Dotinga, Randy, “Coloring the Comic Books," Wired, 07/19/2003, <accessed on January 7 2021>

Dunning, Stefanie. Queer in Black and White: Interraciality, Same-Sex Desire and Contemporary African American Culture. Bloomington: Indiana UP, 2009.

Edenborg, Emil. Politics of Visibility and Belonging: From Russiá s "Homosexual Propaganda" Laws to the Ukraine War. London/New York: Routledge, 2017.

Ellison, Ralph. Invisible Man. New York: Vintage, 1995.

Epstein, Steven. "Gay Politics, Ethnic Identity: The Limits of Social Constructionism." Socialist Review 93, no. 94 (May-August 1987): 9-54.

Fleetwood, Nicole R. Troubling Vision: Performance, Visuality, and Blackness. Chicago: University of Chicago Press, 2011.

Fraser, Nancy. "Rethinking the Public Sphere: A Contribution to the Critique of Actually Existing Democracy." Social Text 25, no. 26 (1990): 56-80.

Gateward, Frances and John Jennings, eds. The Blacker the Ink: Constructions of Black Identity in Comics and Sequential Art. New Brunswick: Rutgers UP, 2015.

Guerrero, Lisa A. Crazy Funny: Popular Black Satire and the Method of Madness. Abingdon/ New York, Routledge, 2020.

Halperin, David M. How to be Gay? Cambridge, Massachusetts: Belknap Press of Harvard UP, 2012.

Hennessy, Rosemary. “Queer Visibility in Commodity Culture.” Cultural Critique 29, (Winter 1994-1995): 31-76.

Hobson, Fred. But Now I See: The White Southern Racial Conversion Narrative. Baton Rouge: Louisiana State UP, 1999.

Johnson, E. Patrick and Mae G. Henderson, eds. Black Queer Studies: A Critical Anthology. Durham/ London: Duke UP, 2005.

Kelley, Robin. Race Rebels: Culture, Politics and the Black Working Class. Free Press, 1994.

Kunka, Andrew J. Autobiographical Comics. London: Bloomsbury, 2018.

Kunka, Andrew J. Howard Cruse. Unpublished manuscript. New Brunswick: Rutgers UP, 2021, forthcoming.

Le Blanc, Guillaume. L'Invisibilité sociale. Paris: PUF, 2009. 
Lewis, John and Andrew Aydin. March. Marietta, Georgia: Top Shelf Productions, 3 vol. , 2013-2016.

Linke, Kai. Good White Queers? Racism and Whiteness in Queer U.S. Comics. Wetzlar: transcript Verlag, 2021. [Open access]

Manchester, Ashley. “Tactility Meets Visuality: Race, Sexuality, and Texture in Howard Cruse's Stuck Rubber Baby.” International Journal of Comic Art 18, no. 1 (2016): 103-117.

Mirzoeff, Nicholas. “The Right to Look.” Critical Inquiry 37, no. 3 (Spring 2011): 473-496.

Morrison, Toni. Playing in the Dark: Whiteness and the Literary Imagination. Cambridge: Harvard UP, 1992.

Mubi Brighenti, Andrea. Visibility in Social Theory and Social Research. Houndmills Basingstoke: Palgrave Macmillan, 2010.

Plissart Marie-Françoise and Jacques Derrida. Droit de regards (1985). Liège: Les Impressions nouvelles, 2010.

Puc, Samantha. "Interview: Howard Cruse dives into queer comics history and his own career as a cartoonist." The Beat, 06/13/2019. < accessed on January 7 2021>

Raiford, Leigh. Imprisoned in a Luminous Glare: Photography and the African American Freedom Struggle. Chapel Hill: University of North Carolina Press, 2011.

Richards, Gary. "Everybody's graphic protest novel: Stuck Rubber Baby and the anxieties of racial difference." In Comics and the U.S. South, edited by Brannon Costello and Qiana J. Whitted, 161-183. Jackson: UP of Mississippi, 2012.

Rifas, Leonard. "Racial Imagery, Racism, Individualism, and Underground Comix.” ImageTXT, Interdisciplinary Comics Studies 1, no. 1 (Spring 2004). <accessed on January 7 2021>

Santos, Jorge J. Graphic Memories of the Civil Rights Movement: Reframing History in Comics. Austin: University of Texas Press, 2019.

Sinfield, Alan. "Diaspora and Hybridity: Queer Identities and the Ethnicity Model." In Diaspora and Visual Culture: Representing Africans and Jews, edited by Nicholas Mirzoeff, 95-114. London/New York: 2000.

Smith, Harrison. "Howard Cruse, Underground Cartoonist and 'Godfather of Queer Comics' Dies at Age 75," The Washington Post, December 4, 2019.

Strömberg, Fredrik. Black Images in the Comics: A Visual History. Seattle: Fantagraphics, 2003.

Tabachnick, Stephen. The Cambridge Companion to the Graphic Novel. Cambridge: Cambridge UP, 2017.

Wanzo, Rebecca, The Content of Our Caricature: African American Comic Art and Political Belonging. New York: New York UP, 2020.

Weaver, Lila Quintero. Darkroom: A Memoir in Black and White. Tuscaloosa: University of Alabama Press, 2013.

Whitlock, Gillian. “Autographics: the Seeing 'I' of the Comics.” Modern Fiction Studies 52, no. 4 (Winter 2006): 965-979.

Wood, Amy Louise. Lynching and Spectacle: Witnessing Racial Violence in America, 1890-1940. Chapel Hill: The University of North Carolina Press, 2009. 


\section{NOTES}

1. Samantha Puc, "Interview: Howard Cruse dives into queer comics history and his own career as a cartoonist," The Beat, 06/13/2019; <accessed on June 19 2020>

2. The word "comix" was used in the late 1960 s to describe subversive, countercultural comics intended for mature readers.

3. Andrew Kunka, Howard Cruse (New Brunswick: Rutgers UP, forthcoming), 16-17.

4. The expression was coined by Fred Hobson in But Now I See: The White Southern Racial Conversion Narrative (Baton Rouge: LSU Press, 1999), 2.

5. Julie Armstrong has identified many of the historical references in this "movement narrative." Julie Buckner Armstrong, "Stuck Rubber Baby and the Intersections of Civil Rights Historical Memory," in Redrawing the Historical Past: History, Memory, and Multiethnic Graphic Novels, eds. Martha J. Cutter and Cathy J. Schlund-Vials (Athens: University of Georgia Press, 2018), 106-128.

6. Howard Cruse, Stuck Rubber Baby (New York: Paradox, DC Comics, 1995), n. p.

7. Kunka, Howard Cruse, forthcoming, 54.

8. Gary Richards, "Everybody's Graphic Protest Novel: Stuck Rubber Baby and the Anxieties of Racial Difference" in Comics and the U.S. South, eds. Brannon Costello and Qiana J. Whitted (Jackson: UP of Mississippi, 2012), 162. In But Now I See: The White Southern Racial Conversion Narrative, Fred Hobson defines the "racial conversion narrative" as "works in which the authors, all products of and willing participants in a harsh, segregated society, confess racial wrongdoings and are 'converted,' in varying degrees, from racism to something approaching racial enlightenment." (Baton Rouge: Louisiana State UP, 1999), 1-2)

9. Simon Dickel, “'Can't Leave Me Behind': Racism, Gay Politics, and Coming of Age in Stuck Rubber Baby," Amerikastudien / American Studies 56, no. 4 "American Comic Books and Graphic Novels" (2011): 633, 630.

10. Jorge J. Santos, Graphic Memories of the Civil Rights Movement: Reframing History in Comics (Austin: U of Texas Press, 2019), 152, 150. Jorge Santos's reading is mostly based on a reading of the lynching of the white gay pro-Black militant Sammy.

11. Hobson, But Now I See, 133.

12. Armstrong, "Stuck Rubber Baby," 126.

13. Kai Linke, who has analysed Cruse's narrative from the perspective of "Gay is the new Black discourses," reaches severe conclusions, in part because he considers that Toland's "homosexuality is portrayed as innate, immutable and absolute," and sees the visual relations in the graphic memoir as a series of "equations" drawn between racism and cis/hetero-sexism, rather than as open to the reader's interpretation of a subjective, focalized narrative," Kai Linke, Good White Queers? Racism and Whiteness in Queer U.S. Comics (Wetzlar: transcript Verlag, 2021), 246, 199-229.

14. Ralph Ellison, Invisible Man (New York: Vintage, 1995), 508, 577.

15. Fredrik Strömberg, Black Images in the Comics: A Visual History (Seattle: Fantagraphics, 2003).

16. Andrew Kunka explains that this episode has an autobiographical origin (Howard Cruse forthcoming), 69.

17. The "Don't Ask, Don't Tell" (DADT) policy was implemented in the U.S. Army in 1993 under President Clinton: it was conceived as a compromise allowing gay men to serve in the Military so long as they concealed their sexual orientation. The Act was repealed by President Obama in December 2010.

18. Nicholas Mirzoeff, “The Right to Look," Critical Inquiry 37, no. 3 (Spring 2011): 476.

19. Cruse, Stuck Rubber Baby, 9. Andrew Kunka notes that Cruse "would regularly use a scene of young boys wrestling as a moment of erotic epiphany" (Howard Cruse, forthcoming), 9.

20. Cruse, Stuck Rubber Baby, 10.

21. Cruse, Stuck Rubber Baby, 8. 
22. Cruse, Stuck Rubber Baby, 28.

23. Cruse, Stuck Rubber Baby, 193. These are the older Toland's words.

24. David M. Halperin, How to be Gay? (Cambridge, Mass.: Belknap Press of Harvard UP, 2012), 196.

25. "L'invisibilité se comprend ainsi comme le fait d'être sans qualités - absence revendiquée ou attribuée » Guillaume Le Blanc, L'Invisibilité sociale (Paris: PUF, 2009), 6.

26. Cruse, Stuck Rubber Baby, 2-3.

27. Cruse, Stuck Rubber Baby, 51.

28. Fredrik Strömberg, Black Images in the Comics: A Visual History (Seattle: Fantagraphics, 2003), 215.

29. Strömberg, Black Images, passim.

30. Cruse, Stuck Rubber Baby, 66.

31. Cruse, Stuck Rubber Baby, 114.

32. Ashley Manchester, "Tactility Meets Visuality: Race, Sexuality, and Texture in Howard Cruse's Stuck Rubber Baby," International Journal of Comic Art 18, no. 1 (2016): 103.

33. Howard Cruse, The Other Sides of Howard Cruse (Los Angeles: Boom!, 2012).

34. Cruse, Stuck Rubber Baby, 18, 50, 52, 94, 113, 164, 192, 198.

35. Wanzo, The Content of Our Caricature: African American Comic Art and Political Belonging (New York: New York UP, 2020), 51

36. Nicholas Mirzoeff, “The Right to Look,” Critical Inquiry 37, no. 3 (Spring 2011): 475.

37. Mirzoeff, "The Right to Look," 473.

38. Wanzo, The Content of Our Caricature, 27.

39. Lisa A. Guerrero, Crazy Funny: Popular Black Satire and the Method of Madness (Abingdon/ New York: Routledge, 2020), passim.

40. Cruse, Stuck Rubber Baby, 70-71.

41. Wanzo, The Content of Our Caricature, 20. "Cartoons using a triangulated structure depict a subjected person or event of interest, and also show someone else's reaction to that person or thing."

42. Guerrero, Crazy Funny, 8.

43. Cruse, Stuck Rubber Baby, 27.

44. Cruse, Stuck Rubber Baby, 26.

45. Cruse, Stuck Rubber Baby, 44.

46. Cruse, Stuck Rubber Baby, 45.

47. Cruse, Stuck Rubber Baby, 122.

48. Amy Louise Wood, Lynching and Spectacle: Witnessing Racial Violence in America, 1890-1940 (Chapel Hill: The U of North Carolina P, 2009), 10.

49. Cruse, Stuck Rubber Baby, 191.

50. Most lynching photographs were taken by mob participants or those sympathetic to the lynching." (Wood, Lynching, 77) With the development of amateur photography in the 1890s, Amy Wood explains, such pictures became more numerous and more widely circulated, in the form of postcards or in entertainment cinema. As the spectacle of lynching became detached from its original context and from the spectators' reactions, its meaning could be transformed and adapted to different purposes. "By the 1930s, these images came to represent, with iconic power, the most grotesque and egregious aspect of lynching, substantiating the notion that lynching was more than crude vigilantism - it was an atrocity. In this respect, the very spectacle of lynching, so vital to the construction and perpetuation of white supremacy, carried with it the tools of its own dismantling." (Wood, Lynching, 220-21) The last phase in the history of lynching photographs occurred when they became so decontextualized that they became "icons of oppression," disconnected from their historical origin. (Wood, Lynching, 269) See also Leigh Raiford, Imprisoned in a Luminous Glare: Photography and the African American Freedom Struggle (Chapel Hill: University of North Carolina, 2011). 
51. Cruse, Stuck Rubber Baby, 177-178.

52. Cruse, Stuck Rubber Baby, 10.

53. Jorge Santos has analyzed in detail the motif of the broken-glass panels, and their role in dismembering the bodies, expressing trauma, and deracializing the history of lynching. "The fragmentation of the traumas depicted in Stuck Rubber Baby may effectively dramatize the plight of White homosexual men in the 1990s," he concludes, "but only by replacing the African Americans at the center of the historical pathos the novel hopes to access. In doing so, it effectively erases African Americans from this history" Santos, Graphic Memories, 171.

54. Nancy Fraser, "Rethinking the Public Sphere: A Contribution to the Critique of Actually Existing Democracy," Social Text 25, no. 26 (1990): 56-80.

55. Cruse, Stuck Rubber Baby, 190, 193.

56. Cruse, Stuck Rubber Baby, 190.

57. Manchester, "Tactility Meets Visuality", 106.

58. Cruse, Stuck Rubber Baby, 178, 181, 192.

59. Cathy J. Cohen, "Punks, Bulldaggers, and Welfare Queens: The Radical Potential of Queer Politics," in Black Queer Studies: A Critical Anthology, eds. E. Patrick Johnson and Mae G. Henderson (Durham/London: Duke UP, 2005), 40.

60. Cruse, Stuck Rubber Baby, 135.

61. The expression is meant as a joke, since Les is crouching on the front seat, but its political implications are compelling.

62. Cruse, Stuck Rubber Baby, 26.

63. Kunka, Howard Cruse, forthcoming, 1.

64. Kunka, Andrew J., Autobiographical Comics (London: Bloomsbury, 2018), 111.

65. Kunka, Howard Cruse, forthcoming, 36-38.

66. Cruse, Stuck Rubber Baby, 48.

67. Santos, Graphic Memories, 152.

68. "[Les's remark] makes the novel's focus on the overlap between racial and sexual oppression clear, linking the biological certainty of blackness (an exceedingly problematic claim) with the notion that homosexuality is an inborn trait." Santos, Graphic Memories, 152.

69. Bayard Rustin (1912-1987), one of the leaders of the March on Washington, was a gay man who later became an advocate for gay rights.

70. Ralph Ellison, Invisible Man (New York: Vintage, 1995), 509.

71. Ellison, Invisible Man, 507.

72. Cruse, Stuck Rubber Baby, 8-9.

73. Patricia Boling, Privacy and the Politics of Intimate Life (Ithaca: Cornell UP, 1996), 142.

74. Cruse, Stuck Rubber Baby, 201.

75. Marlon B. Ross, "Beyond the Closet as Raceless Paradigm" in Black Queer Studies: A Critical Anthology, eds. Johnson, E. Patrick and Mae G. Henderson (Durham/London: Duke UP, 2005), 181.

76. Richards, "Everybody's Graphic Protest Novel"; Linke, Good White Queers? 183-251.

77. On the narrative function of music in Stuck Rubber Baby, see Dickel, "Can't Leave me Behind."

78. Cruse, Stuck Rubber Baby, 204-205.

79. Cruse, Stuck Rubber Baby, 198.

80. Cruse, Stuck Rubber Baby, 201.

81. Howard Cruse, Early Barefootz (Seattle: Fantagraphics, 1990), 91.

82. Cruse, Early Barefootz, 3-4.

83. Cruse, Early Barefootz, 3.

84. Howard Cruse has explained that this outlook was prompted by their use of LSD. "An Afterword about those Psychedelics," Early Barefootz, 101-104.

85. Cruse, Stuck Rubber Baby, 70.

86. Cruse, Stuck Rubber Baby, 164-166. 
87. Cruse, Stuck Rubber Baby, 164.

88. Cruse, Stuck Rubber Baby, 169.

89. An.? "Censorship Roundup," School Library Journal 50/10 (Oct 2004): 26.

90. Frances Gateward and John Jennings, eds., The Blacker the Ink: Constructions of Black Identity in Comics and Sequential Art (New Brunswick: Rutgers UP, 2015), 7.

91. Wanzo, The Content of Our Caricature, 25.

92. Howard Cruse was anxious not to depict the Black community in a clichéd manner, especially with regards to homophobia. See Kunka, Howard Cruse, forthcoming, 52-53.

93. Wanzo, The Content of Our Caricature, 25. There is a subplot in which, by bringing a brick in her handbag to the Russell Park demonstration, Mabel enacts the temptation of responding to violence with violence and runs the risk of being "kicked right out of the movement" Cruse, Stuck Rubber Baby, 75, 110, 135.

94. Hobson, But Now I See, 22.

95. "The right to look is not merely about seeing. It begins at a personal level with the look into someone else's eyes to express friendship, solidarity or love. That look must be mutual, each inventing the other, or it fails. As such it is unrepresentable," Mirzoeff, "The Right to Look," 473.

96. Ross, "Beyond the Closet," 182.

97. Johnson and Henderson, ed. Black Queer Studies, 10.

98. Linke, Good White Queers? 243-44.

99. Ross, "Beyond the Closet," 183.

\section{ABSTRACTS}

Howard Cruse's Stuck Rubber Baby (1995) is a coming-out narrative and a graphic memoir about the civil rights movement in a fictional town in Alabama. It engages with the regime of visuality that renders some minorities invisible, as well as with the need for visibility that comes with political engagement. This essay examines the intersection of race and gender by focusing on the issues of visibility and invisibility. Cruse's graphic novel provides an intersectional picture of what being denied representation and recognition implies. Having been made aware of what being invisible as a subaltern means, the reader realizes the importance of looks of acceptance and recognition given across the lines of race and gender.

\section{INDEX}

Keywords: gender, graphic memoir, comics, civil rights movement, Howard Cruse, LGBT, queer studies

\section{AUTHOR}

NATHALIE SAUDO-WELBY

Université de Picardie 